\title{
Unhappy Families
}

\section{SARAH CefFal}

UNIVERSITY OF SYDNEY

Sara Ahmed

The Promise of Happiness

Duke University Press, Durham, NC, 2010

ISBN 9780822347255

RRP US\$23.95 (pb)

David L. Eng

The Feeling of Kinship: Queer Liberalism and the Racialization of Intimacy

Duke University Press, Durham, NC, 2010

ISBN 9780822347323

RRP US $\$ 23.95(\mathrm{pb})$

For those interested in feeling, a seismic shift is taking place. Despite differences in discipline, object and location, The Promise of Happiness and The Feeling of Kinship embody a shared critical sensibility and a mode of politics that is embedded in the discursive terrain of this shift. Together, these texts track the contexts of nation building in which 'happy families' manifest political investments in how feeling forces identity and its conceptualisation. They variously locate antecedents to the critical import of feeling in contemporary studies of race, gender, sexuality and class, 
in traditional Western philosophy and in the insights of discursive and psychoanalytic analysis.

The task of doing a cultural politics of feeling attests not only to the complexities of affective life, or even to the epistemic challenges ushered in by the truths of feeling, but to the profound changes afoot in cultural landscapes of identity. Transporting the intellectual study of feeling into the discursive terrain of identity augments the terms of analysis that ground the politics of identity; at stake is the ability to critique the tactility of identity as a deployment of power. The shared ground of this seismic shift mobilises registers of feeling to push anti-racist, antisexist and anti-homophobic knowledges beyond the spectre of their epistemic stagnation in identitarian 'identity politics' and the conservatism that multicultural agendas of identity in official state discourses on Western liberalism allow.

The politics of Ahmed's and Eng's projects are thus sutured not only in points of convergence between the stated purviews of postcolonial, queer and feminist analysis, but in the forging of shared sinews of analytic and historical density that subtend their discourse. These sinews are new degrees of nuance and intensity that articulate feeling's becoming; the force of feeling as value, as home, as normal, as that which tells-before we understand-who it is that we are, what we are made up of, and what it is that we are doing.

I was struck by the commitment to refiguring historical linearity through the articulation of grief. My reading is not necessarily situated in as wide a context and with as long enough of a degustation as these texts deserve, but I am fascinated by the coincidence between the political and epistemic work of rethinking 'history' for contemporary movements of identity, and the dis/placing effects of temporalities of feeling within identity's affective structures. This sinew of nuance and intensity, forged in a co-inhabitable reading of the texts, generates new historical contingencies of identity by opening up specific kinds of historical inquiry particular to the feedback of feeling; enfolding diagrams of subjective and structural change are etched in the moment when, in the words of Lauren Berlant, 'the elastic snaps back on the subject who no longer finds traction in the ways of being that had provided continuity and optimism for her'.1 A number of recent calls for papers on the topics of history and the emotions attest to the currency of the authors' desire to 
expand the work of these etchings at the heart of the interface between openings of historical inquiry and the identity politics of feeling.

\section{—GRIEF'S HISTORY}

Each chapter of The Feeling of Kinship reconceptualises the time of feeling according to particular scenarios of cultural difference. The temporality of the politics of feeling needs to be understood in terms that are particular to specific cultural contexts or locales, yet that also dovetail with the broader cultural imperatives informing local grounds of possibility.

The chapter 'The Structure of Kinship' reads The Book of Salt and Happy Together to show how the time and space of European modernity is reframed as a structure of feeling in which the 'universalizing narrative of European consciousness' (67) bestows affective histories to its subjects. ${ }^{2}$ The psychic and affective dimensions of the anticipatory temporality of closeted subjectivity are governed by 'waiting', the "not yet" of historicism'3 (69) and queer liberalism. The life-world of Bình, the protagonist of The Book of Salt, 'emerges only between the time of his Mesdames' departure and arrival, their disappearance and reappearance'. (69) Employed as household chef to Gertrude Stein and Alice B. Toklas 'during the couple's famous residence in Paris as American expatriates', (59) the Vietnamese colonial and exiled queer inhabits 'a structure of feeling that defies the temporal and spatial logic of modernity's ceaseless progress'. (69)

In this chapter, Eng's reading of Wong Kar-wai's film Happy Together also foregrounds the contingency between feeling and temporal indeterminacy. The film's portrayal of Lai and Ho's South-South migration from Hong Kong to Buenos Aires enfolds their 'interminable cycle of abandonment, breaking up, and "starting over"', (79) and 'the impossibility of [their] domesticity', (79) within 'the indeterminate passing of time and space in between capitalist systematization of labor and wages'. (82)

I would like to further examine the connection between modernity's 'disciplining of time and space into the political logic of liberal humanism and the economic logic of liberal capitalism', (69) and the reliance of these constructs on their investments in masculinity. For example, Bình's relationship with Lattimore'a man of dubious racial origins' (71)—is an 'on-again-off-again relationship', (71) 'a 
private without a public', (74) that 'slips in between the cracks of an Enlightenment compulsion to evaluate and interrogate, to organise and know'. (71) In this example, my question is: how would Eng's critique be extended by analysing Bình and Lattimore's mode of inhabitation and its temporal qualities as lacking the certitude of possessive masculine subjectivity, in other words, as structurally feminine?

The 'crossing of fiction into history and history into fiction' (64) in these texts enables a representation of an experience of temporality in which '[d]ifference does not return as sameness'. (74) The epistemic status of fiction enables the construction of 'alternative time and space-other forms of racial knowing and being - that are more than just a negation or reversal of the dominant terms of relation' (75) in the linear progression from modernism to postmodernism that is 'constituted through disavowed and sublated colonial histories of race'. (74) The cultural imperative is to forget. But Eng retrieves the ghostly presence of histories, questioning: 'What possible pasts and what possible futures must be denied in order for this particular narrative of queer freedom and progress to take hold?' (74) This segues into the larger question of the book: 'how does queer liberalism not only depend on but also demand the completion of the racial project, the triumph of a colorblind US society as an achieved and settled past?' (74)

The following chapter, 'The Language of Kinship', makes a slightly different use of time. In the context of transnational adoption, as represented by Deann Borshay Liem's documentary First Personal Plural, ${ }^{4}$ rather than bring into relief modes of being made possible by temporal multiplicity, Eng describes how memories of concrete experiences are erased to produce a temporal linearity that mirrors conventional family embodiments of narrative time. The protagonist of this story, rather than finding ways to be otherwise within 'the suppression of difference ... the collective refusal to see difference in the face of it', (95) is caught in, even immobilised by, the narratives that press upon her. Unlike Bình, Lai and Ho, whose experiences resist or counter-occupy nationalistic process of categorisation, Borshay Liem cannot overcome the fraught experience of cultural and familial dispossession, confessing: “'There wasn't room in my mind for two mothers."' (94) The political context that Eng gives this statement of psychic reality has a relationship to that of the previous chapter, but it is also something altogether different. 
Leaving a country of origin involves mourning 'a host of losses both concrete and abstract'. (115) In the context of diasporic communities, this mourning is managed communally, through the intergenerational and intersubjective experience of racial melancholia. Yet the recognition of the loss of Korea is not permitted by the adoptee's family, who manage 'the adoptee's affect': 'the contraction of Korean history into the privatized boundaries of the white American family is finessed through the management and control of Borshay Liem's emotional life'. (114) Here, the target of managing affect is the management of racial difference.

In Eng's analysis, the erosion of boundaries in the case of transnational adoption is quite different from the rendering of in-betweens that disrupt modernist narratives in The Book of Salt and Happy Together. Whereas the adoptee's affect is managed, it is 'the autonomy of affect's (81) that permits Lai and Ho to 'occupy their own alternative human life-world "in between"', despite the impossibility of their relationship. In First Person Plural, cultural practices smooth over political differences; the assimilation of spatial discord into the smooth temporalities of the neoliberal nation-state enacts a privatisation of race that is also a forgetting of race. The contribution of a feminist perspective could be considered here also: could it be that gender - the gender of Borshay Liem and the gendered structure of the trade in which her experience takes place-is a significant aspect of the structural differences that impede Borshay Liem's access to 'the psychic time and space of the in-between'? (81)

Like Eng, Ahmed draws significantly Freud's theory of melancholy-of the inability to name, avow and mourn certain losses-particularly in her chapter 'Melancholic Migrants'. Both scholars eke out a sort of distortion of linear temporality through unpacking grief, loss and various emotional, psychic and affective states identifiable under the psychoanalytic rubric of melancholia.

Ahmed also finds a return that is a haunting: 'It is the very desire to assimilate, to let the past go, which returns to haunt the nation. It is the migrant who wants to integrate who may bear witness to the emptiness of the promise of happiness'. (158) Immigration is a 'national ideal, a way of imagining national happiness', (158) and yet, it is the experiences of those whose desires are caught in the will to assimilate that show up as failed assimilation; the desire to belong reveals that which jars and rubs and strips and dismantles, the 'attachments that cannot be 
reconciled'. (158) In this context, 'holding on to a memory' gains 'ethical importance ... as a way of keeping a connection to what and who survives in the present'. (158)

Ahmed's reading of the film If These Walls Could Talk $2^{6}$ in the chapter 'Unhappy Queers' reveals the related but differently palpable pain of loss in the context of sexuality. Like Eng, Ahmed complicates the progressive narrative of queer freedom through a theorisation of loss. Ahmed expands the sensitivity of our interpretative gauges to the multiplicity of pressures loss exerts on the subject, and to the myriad manifestations of loss feelings the desire for happiness can entail or represent.

Ahmed locates the representation of feminist and queer movement as that which facilitates the happiness of queer existence: 'Feminist and queer activisms are the mediating point, as "what" must take place to get from happy heterosexuality (which as we know creates unhappiness conditions for queers) to queer happiness.' (107-8) If These Walls Could Talk 2 tells the story of lesbian procreation through reimagining 'the world as if there is no discrimination'. (113) The film is comprised of three short films, each of which follows a different lesbian relationship at a particular historical moment in the United States. Ahmed shows how the 'possibility of injury is displaced into the future, which becomes a promise, as if the future itself is what will overcome injury or any other signs of hurt ... the disturbing thought of discrimination is not allowed to interrupt queer happiness'. (113) This is feeling's shift of the political terrain of identity: having children is not (only) a question of wanting to become like straight people, but of recovery and hope for a better life, a life less burdened by the pain of loss and lack of access to sovereign subjectivity. In Ahmed's words:

This short film shows us the pain that follows from the failure of recognition. Indeed, the happiness of this film reminds us that the desire for recognition is not necessarily about having access to a good life. It is not even necessarily an aspiration for something: rather it comes from the experience of what is unbearable, what cannot be endured. The desire for a bearable life is a desire for a life where suffering does not mean that you lose you bearings, where you become unhoused. (111)

Ahmed's phenomenological understanding of feeling, that privileges the experience of feeling over the autonomy of affect, refigures the political desire for recognition 
from the standpoint of the experience of emotion that is enfolded with the structural lack of recognition. Theorising the frail and jagged edges of bearable life opens the way for a discussion of recognition that is not about the ability of the subject to hold an identity that categorically describes who she or he is but, rather, is about the provision of terms in which a subject has access to further recognition of what they already know to be their own experience.

-HAPPINESS KINSHIPS

Reinterpreting historicity through the time of feeling is one among many connective arcs inscribed at the interface between these texts, which challenge our awareness of the relationship between emotional and affective experience and the nationalistic imperative to manage cultural minorities. Both Eng and Ahmed expand the political horizons of feeling and cultural politics with exciting complexity: both books are brilliant in ways impossible for me to convey in their 'review'.

In seeking to understand the contingency of US colourblindness on the (legislative and cultural) privatisation of race-that Eng calls 'the racialization of intimacy' - structures of feeling (Raymond Williams) are given a psychic life (Freud) as embodiments of the neoliberal refusal to see the public difference of race. In 'following the word happiness' (14) Ahmed examines 'how happiness participates in making things good', (13) reconfiguring the philosophical, political and personal landscape of value that saturates our claims to want to be happy, to make one another happy. The feminist killjoy, the unhappy queer and the melancholic migrant are figures in a discursive structure of happiness that displaces the cause of unhappiness onto those who suffer unhappiness feelings.

One concern I continue to hold regards the ubiquity of 'affect'. In academic circles, I hear affect enunciated as a noun to describe the state of being affected. This enunciation is outside the context of psychology, which is the genealogical context in which 'the affects' are subjectively and objectively perceivable things. There is a slipperiness around the passage of psychological concepts into critical discourse that seems to lose accountability in the generic applicability of affect to all things embodied and relational. Inhabiting a migratory 'between' myself, what I might be hearing is more of a pronunciation than an enunciation. In any case, the concept of affect is still undergoing some challenging interdisciplinary translations and, in 
these, it can be difficult to keep hold of the genealogically intended meaning. It is another project to get to the discursive mechanics supporting the suspiciously current valorisation of affect in relation to other terms, such as sensation and emotion, when we are so caught up in the affective sway of affect's propensity to describe what it is that we are so interested in describing. I do wonder, though, how to get to these mechanics while also making use of this very propensity as so richly and generously bequeathed to critical discourse by Ahmed and Eng.

Eng is wholeheartedly psychoanalytic and embraces Massumi's distinction between emotion and affect.7 My question here, given the predominance of psychoanalysis in the American academy for some time, is: what is happening at this moment when what have had currency as psychoanalytic readings become translated as affective ones? I am curious not only about the translatability of psychoanalysis into affect, which as a moment has a brief history through the work of scholars like Teresa Brennan, but about the recoding of terms. Call me paranoid, but as the language of affect expands, the language of power and power's effects seems to be recede. All the while, 'affect' in The Feeling of Kinship could be genealogically located as a use of psychoanalysis in the discursive analysis of power.

While continuing to utilise psychoanalysis with phenomenology to think about affect as 'sticky'-'[a]ffect is what sticks, or what sustains or preserves the connection between ideas, values, and objects' (230)-emotion doesn't even make an appearance in the appendix of The Promise of Happiness. ${ }^{8}$ The discursive tide of affect triumphs, despite Ahmed's productive resistance to the pressure to privilege either term in The Cultural Politics of Emotion. ${ }^{9}$ I do think we need to be wary about the ease which with the conceptual register of affect supersedes terms such as power, effect and emotion, in part merely because such a supersession, while generative, also acts to flatten, universalise or cohere possibilities for thinking feeling, possibilities that Eng and Ahmed are so committed to keeping alive and open.

The idea of happiness and the idea of family are so intractable to the daily shape of emotional experience, that it is with the politics of these terms 'happiness' and 'kinship' that a politics of feeling begins. The feeling of happiness and the feeling of kinship slip and slide in and out of the texts; as Ahmed follows the word happiness, I follow the feelings that come and go in the authors' followings. As their 
etchings are in the betweens of affective and psychic structures of self and world, original carvings in zones of analytic indeterminacy, it is certainly not the case that some clumsy desire for 'representation' is getting in the way of how we really feel. I did, however, so often crave more of an attentiveness to the quality of the power of these feelings of kinship and happiness; ${ }^{10}$ feelings are made political in their discourse, of course, but also because of the capacities of our feeling bodies to soak up and articulate their cultural refrains. I know that these feelings are there, the objects of these books slipping and sliding as feelings do: it is not a criticism, I just want more. And I do, in the words of Leona, 'just want to be, happy'.11

Sarah Cefai's doctoral thesis, titled 'Critical Feelings: A Genealogy of the Epistemology of Feeling in Queer Feminist Movement', is due to be submitted in March 2011. Her work examines the political registers of feeling that play out in the experience of cultural difference.

\section{-NOTES}

${ }^{1}$ Lauren Berlant, 'Thinking about Feeling Historical', Emotion, Space and Society, vol. 1, 2008, pp. 4-9, p. 4.

2 Monique Truong, The Book of Salt, Houghton Mifflin, Boston, 2003.

${ }^{3}$ Dipesh Chakrabarty, Provincializing Europe: Postcolonial Thought and Historical Difference, Princeton University Press, Princeton, 2000, p. 8.

${ }^{4}$ First Person Plural, directed by Deanne Borshay Liem, National Asian American Telecommunications Association, San Francisco, 2000.

5 Brian Massumi, Parables for the Virtual: Movement, Affect, Sensation, Duke University Press, Durham, 2002.

${ }^{6}$ If These Walls Could Talk 2, directed by Jane Anderson, Martha Coolidge, Anne Heche, HBO, 2000.

7 In brief, Massumi's distinction between affect and emotion asserts that while emotions are qualified intensities that pass through the lived construction of meaning in language, affects are unqualified intensities, resistant to critique. Massumi, among a growing number of theorists, takes his concept of affect from Gilles Deleuze. His distinction and interpretation of Deleuze enjoys interdisciplinary 
acceptance from many scholars working on affect, in fields such as geography, sociology, and cultural studies. See Parables for the Virtual.

8 To illustrate, Ahmed describes the image of the happy housewife as having an 'affective power', (53) whereas Eng talks about sites of 'affective density', (70) and describes crying as a 'language of affect'. (114) This deserves further illustration and discussion, which I hope to stimulate.

${ }^{9}$ Sara Ahmed, The Cultural Politics of Emotion, Edinburgh University Press, Edinburgh, 2004.

10 Particularly reading Ahmed, whose passion for phenomenology seems to bring feelings closer, and yet somehow all the more apart.

11 Leona Lewis, 'Happy', Syco, 2009. In the chapter 'Feminist Killjoys', (50-87) Ahmed locates the feminist subject as a 'killjoy', refusing to share in happiness causes that are structurally replicated and cover over the pain of others. After identifying how the promise of happiness embodied by the 'happy housewife' (51) produces the 'loss of other possible ways of living', (79) which lies behind 'how happiness demands adjusting your body to world that has already taken shape,' (79) Ahmed resolves that: 'Feminism involves challenging the very "pressure" of happiness, the way it restricts the possibilities for finding excitement, of being excited.' (69) I cannot help think, however, that at work in this distinction is a feeling of happiness with an epistemological status that always recedes from view. Aren't feelings of being excited, of feeling happy, always going to be caught up in a hegemony of 'happiness scripts' (59) at some level of interpretation of the subject? While Ahmed claims to only follow 'the word' happiness, (198) there is more to say about 'being excited' as happiness feelings, and as feelings that tell us whether or not we have become 'happy housewives'.

Shortly after Ahmed's presentation of 'Killing Joy' in Sydney in September 2009, singer Leona Lewis (winner of the British television talent series The X Factor (Talkback Thames, FremantleMedia, SYCOtv) in 2008) released the single 'Happy'. The chorus goes: 'So what if it hurts me | So what if I break down | So what if this world just throws me off the edge | And my feet run out of ground | I gotta find my place | I wanna hear my sound | Don't care about all the pain in front of me | I'm just trying to be I HAPPY'. I would like to know what Ahmed thinks about Leona's happiness. We don't know what will make Leona happy, and she might not know herself, but we do know that she doesn't want to 'stand by the side ... safe as could be'. Is Leona's happiness a feminist script that slips and slides between figures such as the happy housewife and the hag; as that which unsettles the binary frame delineating that which is imposed from that which resists? Or is Leona's happiness that which we move toward as we are moved by the sound of her moving, the movement she portrays in the emotional honesty of her voice: 'I just want to be...'? How is this betweenness, and the recognition that we might not know what will make us happy—only what happiness is when we feel our hope for its becomingimportant to our re-engagements with happiness as 'the political horizon in which feminist claims are made'? (59) 